\title{
Penggunaan Video Edukasi dalam Meningkatkan Pengetahuan Remaja tentang Covid-19
}

\author{
Bulan Kakanita Hermasari*, Yunia Hastami, M. Nur Dewi Kartikasari \\ Program Studi Kedokteran, Fakultas Kedokteran, Universitas Sebelas Maret \\ *dr.bulan.kakanita@staff.uns.ac.id
}

\begin{abstract}
Abstrak
Pandemi covid-19 telah menyebabkan dampak signifikan pada berbagai tatanan kehidupan bermasyarakat. Salah satu upaya mencegah penyebaran penularan penyakit covid-19 adalah dengan melakukan protocol kesehatan ketat. Untuk menyebarluaskan protocol kesehatan ini dibutuhkan edukasi kesehatan secara massif dari berbagai pihak kepada semua kalangan masyarakat, salah satunya adalah kepada remaja usia sekolah. Remaja memiliki potensi untuk melakukan edukasi kepada teman sebaya dan keluarga terdekatnya. Kegiatan pengabdian masyarakat ini dilakukan dengan menyusun suatu video singkat tentang protocol kesehatan Covid-19 yang disampaikan kepada remaja usia sekolah, dalam hal ini siswa SMP dan SMA sederajat. Untuk mengetahui efektivitas video edukasi terhadap peningkatan pengetahuan subyek, dilakukan tes sebelum dan sesudah pemberian edukasi melalui video. Dalam kegiatan pengabdian masyarakat ini, didapatkan peningkatan secara signifikan pengetahuan subyek tentang covid-19. Hal ini menujukkan bahwa video yang disusun bermanfaat sebagai media edukasi tentang covid-19.
\end{abstract}

Kata kunci-covid-19, media edukasi, remaja, pengabdian

\section{Pendahuluan}

Penyakit coronavirus (COVID-19) pertama kali dilaporkan di Wuhan, Cina pada Desember 2019, lalu menyebar secara bertahap ke berbagai negara hingga ditetapkan sebagai pandemik global oleh WHO pada Maret 2020 (Kemenkes RI, 2020; Nicola et al., 2020; Shaw, Kim, \& Hua, 2020). COVID-19 adalah penyakit respiratorik akut yang disebabkan SARS-CoV-2. Penyakit ini menyebabkan mortalitas yang cukup tinggi utamanya pada orang lanjut usia dan dengan faktor medis pemberat seperti penyakit kardiovaskuler, diabetes, dan kanker (World Health Organization, 2020). Akibat dari penyebarannya yang sangat tiba-tiba dan cepat, COVID-19 menyebabkan perubahan signifikan pada system pelayanan kesehatan global yang memiliki dampak pada berbagai aspek kehidupan manusia. Terdapat beberapa sektor yang dipengaruhi oleh penyebaran penyakit ini, seperti kesehatan, pertanian, industri, pariwisata, dan juga pendidikan. COVID-19 telah mempengaruhi semua tingkatan sistem pendidikan, mulai dari sekolah dasar hingga pendidikan tinggi (Bauchner \& Sharfstein, 2020; Ferrel \& Ryan, 2020; Nicola et al., 2020). Berbagai negara telah menerapkan berbagai kebijakan, seperti penutupan fasilitas pendidikan secara nasional. Hal tersebut mengakibatkan terjadinya berbagai perubahan dalam kegiatan belajar mengajar yang berpindah dari institusi pendidikan ke rumah. Adanya ketidakpastian berapa lama situasi pandemi ini akan berlangsung mengarah pada suatu kondisi yang disebut new normal life, di mana karantina dan physical distancing tetap akan diperlukan dalam kehidupan bermasyarakat (Shaw et al., 2020). Salah satu syarat penerapan new normal life adalah keterlibatan masyarakat secara partisipatif dalam proses transisi dan penerapan new normal life. Selain itu, WHO juga menyatakan bahwa perlu terdapat suatu mekanisme untuk mengkaji persepsi, kesiapan dan tingkah laku masyarakat dalam menghadapi new normal life (World Health Organization, 2020). Salah satu komponen 
masyarakat yang dapat terlibat dalam proses ini adalah remaja.

Remaja dianggap hampir dewasa karena telah mempunyai mental, sosial, emosional dan fisik yang matang, demikian juga dengan pemikirannya. Kematangan mental dan emosional ini tentu saja tidak diikuti oleh perilakunya, khususnya di masa pandemi Covid-19 saat ini dengan penerapan pembelajaran jarak jauh secara daring. Resiko tertular penyakit pada remaja lebih rendah dibandingkan kelompok usia yang lebih tua, tetapi remaja dapat berperan sebagai orang tanpa gejala (OTG) yang memiliki potensi untuk menularkan penyakit Covid19 kepada orang dewasa atau lansia (Zimmermann \& Curtis, 2020). Beberapa literatur melaporkan bahwa banyak anak muda umur 15-25 tahun terpapar Covid-19 karena kebiasaan nongkrong di kafe, warung kopi atau angkringan dengan tidak menjaga jarak dan melepas masker (Nugeraha, 2021). Oleh karena itu, dibutuhkan intervensi kepada remaja-remaja ini agar dapat lebih mengetahui tentang Covid-19 dan pencegahannya sehingga dapat menerapkan protokol kesehatan dengan baik.

Penggunaan video sebagai media edukasi kesehatan telah banyak digunakan seiring dengan peningkatan kemajuan teknologi informasi saat ini (Aeni \& Yuhandini, 2018; Lestari, Nurhaeni, \& Hayati, 2018). Video adalah suatu proyeksi yang mengandung gambar yang bergerak dan suara yang dapat menyampaikan pesan tertentu. Penggunaan video dikatakan lebih efektif dibandingkan gambar karena menampilkan obyek yang mendekati benda ataupun suara yang alamiah (Sari, 2019). Oleh karena itu penggunaan video dapat memudahkan penyerapan pengetahuan karena melibatkan indra pendengaran dan penglihatan yang dapat mengaktifkan kerja otak sebagai working memory (Steffes \& Duverger, 2012). Kegiatan pengabdian masyarakat ini berupa edukasi tentang covid-19 kepada remaja usia sekolah menggunakan video.

\section{Metode Pelaksanaan}

Metode pelaksanaan yang digunakan yaitu kuantitatif dan kualitatif. Data yang dibutuhkan didapatkan dari penyebaran video edukasi, kuis dalam Google Form. Hasil dari data penyebaran kusioner menjadi data penting untuk melakukan kegiatan yang tepat dan penerapan media yang tepat kepada responden. Sedangkan data penyebaran video edukasi menjadi data kegiatan yang dilakukan selama kegiatan pengabdian ini. Penilaian dan pendapat tentang persepsi terhadap topik dan video edukasi atau pelaksanaan kegiatan yang sudah dilaksanakan didapat dari data wawancara menggunakan media Whatsapp yang dilaksanakan diakhir kegiatan.

\section{Hasil Dan Pembahasan}

Pelaksanaan kegiatan pengabdian masyarakat telah dilaksanakan pada bulan Agustus-Oktober 2020. Kegiatan pengabdian masyarakat berupa penggunaan video sebagai media edukasi Covid-19 kepada remaja usia sekolah ini terdiri dari beberapa tahap, yaitu:

1. Persiapan

Tahap ini adalah tahap penentuan topik dan pembuatan video. Topik yang dipilih adalah berkaitan dengan beberapa protokol kesehatan pencegahan dan mitos atau hoaks terkait Covid-19, seperti cuci tangan, berjemur, penggunaan masker dan alkohol, serta olahraga. Video yang disusun berdasarkan poster-poster edukasi mahasiswa kedokteran UNS tersebut berdurasi 2 menit agar tidak terlalu membosankan bagi obyek edukasi.

2. Pelaksanaan

Pada tahap ini dilakukan penyebaran media edukasi kepada sasaran edukasi yaitu remaja usia sekolah, dalam hal ini siswa Sekolah Menengah Pertama (SMP) dan Sekolah Menengah Atas (SMA) atau yang sederajat. Video edukasi disebarkan melalui aplikasi Whatsapp kepada beberapa siswa SMP/ SMA yang dikenal oleh penulis. Sebelum dan sesudah pemberian (pre-test dan post-test) video edukasi diberikan kuis yang berisi soal-soal singkat tentang isi video edukasi. Soal yang diberikan berupa pertanyaan dengan jawaban benar dan salah. Responden diminta menjawab soal dengan memilih jawaban benar atau salah sesuai dengan pengetahuan yang dimilikinya. Hal ini ditujukan untuk mengetahui efektivitas dari edukasi yang diberikan yaitu adanya peningkatan pengetahuan. Sejumlah tiga puluh (30) orang bersedia mengisi pre-test dan post-test, dan melihat video edukasi.

Pada tahap ini juga dilakukan pengunggahan video edukasi pada akun Youtube salah satu penulis ((1) Ayo cegah penularan COVID-19 - YouTube), agar video dapat dilihat oleh masyarakat secara luas. 

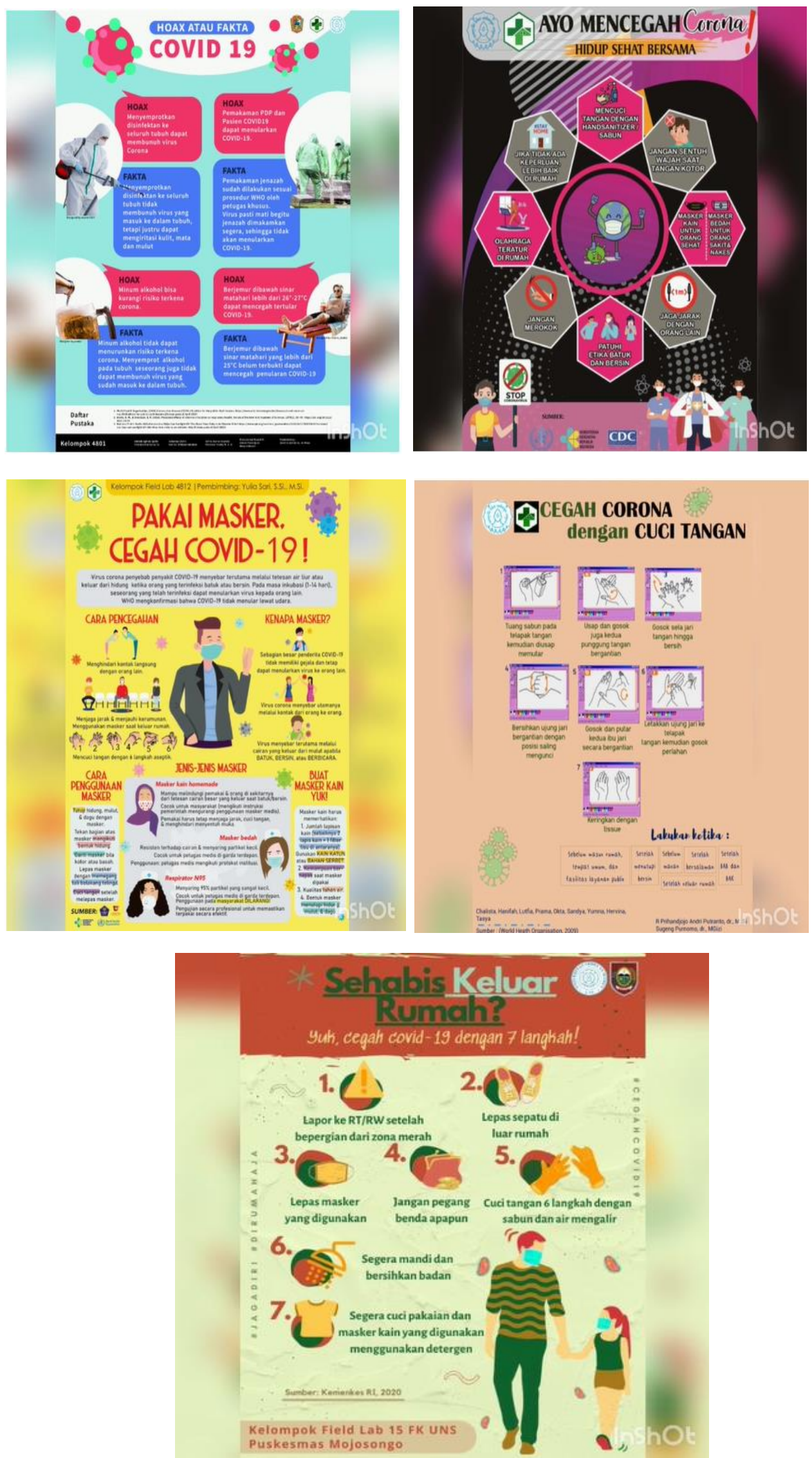

Gambar 1. Bahan Video Edukasi 
Tabel 1. Karakteristik Responden

\begin{tabular}{cc}
\hline Karakteristik & Jumlah (Persentase) \\
\hline Jenis Kelamin & \\
$-\quad$ Laki-laki & $7(23.3 \%)$ \\
$-\quad$ Perempuan & $23(76.7 \%)$ \\
Tingkat Pendidikan & \\
$-\quad$ SMP atau sederajat & $11(36.7 \%)$ \\
$-\quad$ SMA atau sederajat & $19(63.3 \%)$ \\
\hline
\end{tabular}

Tabel 2. Distribusi Skor Pre-test dan Post-test

\begin{tabular}{lccc}
\hline Jenis Tes & Nilai minimal & Nilai maksimal & Mean \\
\hline Pre-test & 1 & 10 & 7.47 \\
Post-test & 8 & 10 & 9.6 \\
\hline
\end{tabular}

Tabel 3. Pertanyaan Kuis Pre-test dan Post-test

\begin{tabular}{|c|c|}
\hline Nomor Soal & Pertanyaan \\
\hline 1 & $\begin{array}{l}\text { Menyemprotkan desinfektan ke seluruh tubuh dapat membunuh virus corona-19 yang } \\
\text { masuk ke tubuh }\end{array}$ \\
\hline 2 & Minum alkohol diatas $70 \%$ dapat mengurangi risiko sakit akibat Virus Corona-19 \\
\hline 3 & $\begin{array}{l}\text { Berjemur di bawah sinar matahari dengan suhu lebih dari } 25^{\circ} \text { dapat mencegah tertular } \\
\text { Virus Corona-19 }\end{array}$ \\
\hline 4 & $\begin{array}{l}\text { Cuci tangan dengan sabun dan air mengalir lebih efektif membunuh virus dibandingkan } \\
\text { menggunakan hand sanitizer }\end{array}$ \\
\hline 5 & $\begin{array}{l}\text { Ada } 6 \text { langkah cuci tangan menurut WHO, urutannya adalah menggosok telapak tangan, } \\
\text { punggung tangan, sela-sela jari, gerakan mengunci jari-jari tangan, menggosok ibu jari, } \\
\text { terakhir memutar ujung jari ke telapak tangan yang lain }\end{array}$ \\
\hline 6 & $\begin{array}{l}\text { Masker N95 sangat disarankan untuk digunakan masyarakat umum karena paling efektif } \\
\text { menyaring } 95 \% \text { partikel yang sangat kecil }\end{array}$ \\
\hline 7 & Masker yang efektif harus menutup hidung, mulut dan dagu \\
\hline 8 & $\begin{array}{l}\text { Setelah memakai faceshield, kita tidak perlu lagi mengenakan masker karena sudah } \\
\text { terlindung dari percikan ludah orang lain }\end{array}$ \\
\hline 9 & $\begin{array}{l}\text { Olah raga teratur yang dilakukan bersama dengan teman-teman dapat mencegah } \\
\text { penularan covid-19 }\end{array}$ \\
\hline 10 & $\begin{array}{l}\text { Penderita Covid-19 bisa tidak menunjukkan gejala sakit, namun dapat menularkan virus } \\
\text { ke orang lain }\end{array}$ \\
\hline
\end{tabular}

3. Tahap Evaluasi

Pada tahap ini dilakukan analisis dan evaluasi dari nilai pre-test dan post-test untuk mengukur peningkatan pengetahuan dari responden terkait topik edukasi yang diberikan. Selain itu juga dilakukan wawancara melalui Whatsapp kepada responden memgenai video edukasi yang diberikan. Hal ini untuk mengetahui bagaimana persepsi dari responden terkait video dan topik edukasi. Analisis uji beda nilai pre-test dan posttest menggunakan Uji Paired t-test karena data terdistribusi normal. Dari Uji Paired t-test ini didapatkan terdapat perbedaan signifikan dari rerata nilai pre-test dan post-test responden. Hal ini menunjukkan bahwa video edukasi dapat meningkatkan pengetahuan responden terkait covid-19.

Tabel 4. Hasil Uji Beda Nilai Pre-Test dan Post Test

\begin{tabular}{lcccc}
\hline & Rerata & selisih & IK95\% & Nilai p \\
\hline Pre-test & 7.47 & $-2.13(2.04)$ & $1.37-2.9$ & 0.00 \\
Post-test & 9.6 & & & \\
\hline
\end{tabular}

Berdasarkan wawancara kepada responden didapatkan bahwa responden merasa video edukasi yang digunakan bermanfaat dan juga menarik: 


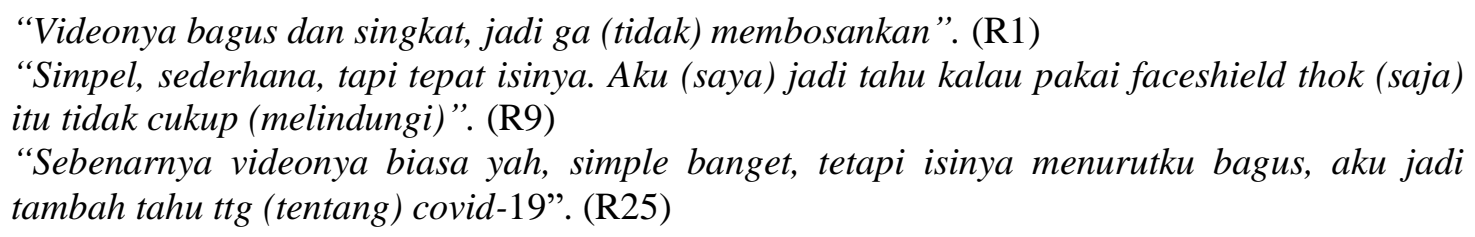

Tingkat pengetahuan responden sebelum diberikan video edukasi memiliki pengetahuan yang cukup, sementara setelah diberikan intervensi dapat dikatakan baik karena mengalami kenaikan pengetahuan. Hasil penelitian ini sejalan dengan Aeni \& Yuhandini (2018) bahwa terjadi peningkatan pengetahuan responden setelah diberikan edukasi dengan media berupa video. Pemberian edukasi dilakukan agar dapat meningkatkan pengetahuan responden tentang covid-19 karena di dalam edukasi diberikan materi yang dikemas dalam bentuk video singkat yang menarik sehingga responden secara langsung dapat memperoleh informasi.

\section{Kesimpulan \\ Kegiatan pengabdian masyarakat berupa edukasi covid-19 kepada remaja usia sekolah ini telah berjalan baik dan lancer. Efektivitas dari edukasi Covid-19 menggunakan video ini ditunjukkan dengan adanya peningkatan pengetahuan responden tentang covid-19. Selain itu, responden juga merasa isi dan video edukasi tersebut bermanfaat bagi mereka. Oleh karena itu, dapat disimpulkan bahwa kegiatan pengabdian masyarakat ini dapat memberikan pemahasam kepada remaja usia sekolah mengenai protocol pencegahan, fakta dan hoax mengenai Covid-19. Harapannya dengan adanya peningkatan pemahaman, responden dapat menjadi agen educator bagi keluarga, teman, dan masyarakat sekitar mereka sehingga kepatuhan masyarakat terhadap protokol kesehatan Covid-19 dapat meningkat.}

\section{Ucapan Terima Kasih}

Penulis mengucapkan terima kasih kepada seluruh responden yang bersedia secara sukarela menjadi obyek dalam kegiatan pengabdian masyarakat ini.

\section{Daftar Pustaka}

Aeni, N., \& Yuhandini, D. S. (2018). Pengaruh Pendidikan Kesehatan Dengan Media Video Dan Metode Demonstrasi Terhadap Pengetahuan SADARI. Care : Jurnal Ilmiah Ilmu Kesehatan, 6(2), 162. https://doi.org/10.33366/cr.v6i2.929

Bauchner, H., \& Sharfstein, J. (2020). A Bold Response to the COVID-19 Pandemic: Medical Students, National Service, and Public Health. JAMA - Journal of the American Medical Association, 19-20. https://doi.org/10.1001/jama.2020.6166

Ferrel, M. N., \& Ryan, J. J. (2020). The Impact of COVID-19 on Medical Education. Cureus, 12(3), 10-13. https://doi.org/10.7759/cureus.7492

Kemenkes RI. (2020). Pedoman Pencegahan dan Pengendalian Coronavirus Disease (COVID-19). Germas, 0-115.

Lestari, Y., Nurhaeni, N., \& Hayati, H. (2018). Penerapan Mobile Video Efektif Meningkatkan Pengetahuan Dan Sikap Ibu Dalam Menurunkan Lama Diare Balita Di Wilayah Puskesmas Kedaton Bandar Lampung. Jurnal Keperawatan Indonesia, 21(1), 34-42. https://doi.org/10.7454/jki.v21i1.546

Nicola, M., Alsafi, Z., Sohrabi, C., Kerwan, A., Al-jabir, A., Iosifidis, C., ... Agha, R. (2020). The socio-economic implications of the coronavirus pandemic ( COVID-19): A review. International Journal of Surgery, 78(March), 185-193. https://doi.org/10.1016/j.ijsu.2020.04.018

Nugeraha, P. (2021). Gaya Hidup Remaja Di Masa Pandemic Dan Dampaknya Terhadap Keputusan Berkunjung Ke Ritel Modern. SOSIOLOGI: Jurnal Ilmiah Kajian Ilmu Sosial Dan Budaya, 23(Vol 23 No 1 (2021): SOSIOLOGI: Jurnal Ilmiah Kajian Ilmu Sosial dan Budaya), 63-73. Retrieved from http://jurnalsosiologi.fisip.unila.ac.id/index.php/jurnal/article/view/57/54

Sari, P. (2019). Analisis terhadap kerucut pengalaman Edgar Dale dan keragaman gaya belajar untuk memilih media yang tepat dalam pembelajaran. Mudir: Jurnal Manajemen Pendidikan, I(1), 58-78. Retrieved from https://ejournal.insud.ac.id/index.php/MPI/article/view/27

Shaw, R., Kim, Y., \& Hua, J. (2020). Governance, technology and citizen behavior in pandemic : Lessons from COVID-19 in East Asia. Progress in Disaster Science, 6, 100090.

https://doi.org/10.1016/j.pdisas.2020.100090 
Steffes, E. M., \& Duverger, P. (2012). Edutainment with videos and its positive effect on long term memory. Journal for Advancement of Marketing Education, 20(1), 1-10.

World Health Organization. Infection Prevention and Control guidance for Long-Term Care Facilities in the context of COVID-19 (2020).

Zimmermann, P., \& Curtis, N. (2020). Coronavirus infections in children including COVID-19: An overview of the epidemiology, clinical features, diagnosis, treatment and prevention options in children. Pediatric Infectious Disease Journal, 39(5), 355-368. https://doi.org/10.1097/INF.0000000000002660 